\title{
БИОКОПОЗИЦИОННЫЕ МАТЕРИАЛЫ ДЛЯ РЕГЕНЕРАЦИИ КОСТНОЙ ТКАНИ И ПОДАВЛЕНИЯ ИНФЕКЦИОННЫХ ВОСПАЛЕНИЙ
}

\section{Т.С. Серегина ${ }^{1,2}$, Е.А. Филимонова', А.Р. Сатаева', И.С. Колесникова', Е.В. Ивановская', В.В. Зайцев ${ }^{2}$, В.А. Дятлов'}

${ }^{1}$ Российский химико-технологический университет имени Д. И. Менделеева, 125047, Россия, Москва, Миусская площадь, 9.

2ФГБУ «НМИЦ ТО им. Н.Н. Приорова», 127299, Россия, Москва, ул. Приорова, 10.

${ }^{3}$ Институт тонких химических технологий имени М. В. Ломоносова, 119435, Россия, Москва, Малая Пироговская ул., 1, с.5.

DOI: 10.19163/MedChemRussia2021-2021-399 E-mail: tatiana.seregina.2016@yandex.ru

Несмотря на многочисленные достижения современной медицины, ортопедические инфекции продолжают оставаться одними из серьезнейших осложнений. Ортопедическая инфекция - сложный длительный процесс, порой заканчивающийся радикальными хирургическими вмешательствами, инвалидизацией пациентов и требует больших затрат для системы здравоохранения. Используемый в настоящее время подход хирургического вмешательства с последующим применением длительного курса антибиотиков достаточно часто влечет за собой побочные эффекты и токсичности. В связи с этим все активнее разрабатываются способы локального подавления бактериальных инфекций. Помимо этого, за последние годы было выявлено, что помимо борьбы с инфекцией необходимо параллельно вызывать регенерацию пострадавшей ткани для ускорения выздоровления пациента [1]. В качестве такого комплексного материала может выступать полисахаридный гель, включающий в себя нанокорпускулярные носители. В данном случае антибактериальный гидрогель на основе декстрана, гидроксиэтилкрахмала или гиалуроновой кислоты, является одновременно носителем антибиотика широкого спектра действия, выделяющегося исключительно в ходе бактериальной атаки, а также матрицей для инкапсулированных физиологически активных веществ [2]. Наноносители представляют собой двуслойные капсулы, внутренняя твердая стенка которых состоит из полиэтил-2-цианоакрилата, а внешняя жидкая мембрана, схожая с клеточной плазмолеммой, получена путем обработки капсулы фосфолипидом. Внутри капсул содержатся вещества, присутствие которых необходимо на стадии ранозаживления и регенерации поврежденной ткани.

\section{Литература}

[1] Waghmare A, Saxena NK, Gupta S, Khan S. Use of biodegradable materials as local antimicrobial carriers in orthopedic infections. J Orthop Spine 2019; 7, 51-6.

[2] Dyatlov V.A., Seregina T.S., Luss A.L., Zaitsev V.V., Artyukhov A.A., Shtilman M.A., Chumakova A.S., Kushnerev K.S., Tsatsakis A., Mezhuev Y. Immobilization of amikacin on dextran: biocomposite materials that release an antibiotic in the presence of bacterial dextranase. 2021; 70(6), 837-844. 